\title{
Perception of the Indian Working Women Considering Equity as an Investment Avenue: An Empirical Study
}

\author{
P Hemavathy* and S Gurusamy ${ }^{\dagger}$
}

\begin{abstract}
This long-lasting volatility in the stock market since the global financial crisis has been disappointing issue for the retail investors to invest in equity markets. Due to high volatility, new clients are scared to burn their fingers and existing investors are uncomfortable in roiling their portfolios. Retail investors are often persuading into inappropriate investment decisions allured by the vested interest. Dividends and capital gains, Source for Retirement planning, Capital Investment Preservation are the major rationale behind the stock market participation Inadequate returns, Inadequate information, Inadequate financial resources, Fear of losing the capital are the major reasons which resist the stock market participation among the Indian Working. This paper attempts to study the influence of demographic variables on the reasons which facilitate the stock market participation and reasons for resistance among the Indian working women to make equity investment. The researcher applies one way ANOVA has been employed to establish the influence of
\end{abstract}

* UGC-Senior Research Fellow, Full time Doctoral Research Scholar, Department of Commerce, University of Madras, Chennai, India; chennaihema@rediffmail.com

† Professor and Head, Department of Commerce, University of Madras, Chennai, India; professorsg@yahoo.com 
demographic variables on the reasons which facilitates and resist stock market participation among Indian Working Women. Results reveal that Indian working women's age, marital status, education, income, role in the family and the source of information about the investment avenue serves as the best proxy variables to determine the working women's preference for equity as an investment avenue. The researcher concludes that retail investors are considered as the backbone to the equity market. There is zilch superior way of empowering the investor than taming their financial literacy among the Working women.

Keywords: Financial knowledge, Retail investors, Working women, Occupation, Annual savings, Capital gains, Stock market participation, Financial literacy

\section{Introduction}

In India, capital markets have been playing a gradually more crucial role, in influencing the rapidity and prototype of economic growth and the stock exchange are a crucial establishment of the capital market as it provides an structured market platform for manifest price discovery. In the year 2013-14, Indian equity markets inclined to a novel sky-scraping position resulting from an enhanced scenario of global financial markets, exchange rate adjustments, and anticipation of electoral outcomes. The beginning of 2014 has witnessed the escalating flow of capital, new pinnacle for benchmark indices and market capitalization which has carved out an investor's encouraging climate for investment. India has an awful retail participation in equity markets. There is an unambiguous upheaval to bring the retail investor back into the stock markets. This circumstance strikes a chord of 2007, when the stock markets hit all time highs and there was euphoria across the nation. Even though Indian stock market has stretched in the post liberalization era, with regard to volatility the market does not demonstrated any momentous transform. This long-lasting volatility in the stock market since the global financial crisis has been disappointing issue for the retail investors to invest in equity markets. Due to high volatility, new clients are scared to burn their fingers and existing investors are uncomfortable in roiling their 
portfolios. The initiative of long term investment is previously to be embedded in the retail investor's mind set. Retail investors are often persuading into inappropriate investment decisions allured by the vested interest. Dividends and capital gains, Source for Retirement planning, Capital Investment Preservation are the major rationale behind the stock market participation (Gerardi, K., Goette, L., \& Meier, S. 2010). Inadequate returns, Inadequate information, Inadequate financial resources, Fear of losing the capital are the major reasons which resist the stock market participation among the Indian Working Women (Yosef Bonaparte and Frank J Fabozzi 2011, Yasser Alhenawi, Khaled Elkhal 2013 Van Rooij, Maarten, Annamaria Lusardi and Rob Alessie 2007.). This paper attempts to study the influence of demographic variables on the reasons which facilitate the stock market participation and reasons for resistance among the Indian working women to make equity investment.

\section{Review of Literature}

Mahastanti, Linda Ariany and Hariady, Edy (2014) examines the factors affecting the stock investment decisions of potential female investors in Indonesia. The author highlights the application of the theory of planned behavior (TPB) in examining factors affecting the stock investment decisions. Finally the researchers focus on the influence of perceived behavioral control and risk preference on intention to purchase financial products.

Geng Li (2014) highlights the significance of information sharing regarding household financial decisions. The researcher uses the panel Study of Income dynamics, and finds that household investors' likelihood of entering the stock market within the subsequent is about 20 per cent to 30 per cent higher if the parents or children had entered the stock market during the previous five years.

Yasser Alhenawi, Khaled Elkhal (2013) examines the relationship between financial knowledge and long term financial planning. This study is significant in the light of recent financial chaos and the current level of economic uncertainty. Survey responses from US households are analyzed using statistical tools analysis of 
variance, subgroup analysis and logistic regressions. The author find that surveyed households are financially knowledgeable, but exhibit poor financial planning skills. Results exhibit that correlation between knowledge and financial planning is low. The authors suggest that to promote financial literacy the public policies must strive to embolden financial education during early stages of life; preferably during college years.

Jackson Gary (2012) attempts to explain on the investors risk awareness. The author finds that most investors lack the level of risk. Further the author mention that few investors have a good understanding of investment risk.

Spectrum High Net Worth Advisor Insights (2012) focuses on how women reacted to chaotic stock market condition in the US. The report highlights that in unprecedented stock market volatility, women have become more cautious and thoughtful with regard to household spending.

Raquel Fonseca et.al (2012) examines potential explanations for the gender gap in financial literacy, including the role of marriage and who within a couple makes the financial decisions. The authors investigate the socioeconomic and demographic factors associated with the gender gap in financial literacy using multivariate regression analysis and Blinder-Oaxaca decomposition. The authors find that decision making within couples depends on the relative education of spouses. Finally, the researchers suggest that with approximately equal education achievement by gender, financial decision making should also be approximately equal by gender, although within an individual household it will depend upon the relative levels of the spouses.

Georgarakos, Dimitris and Pasini Giacomo (2011) investigate the significance of both trust and sociability for stock market participation and for differences in stockholding across Europe. The authors find that the effect of trust is stronger in countries with limited participation and low average trust, offering an explanation for the remarkably low stockholding rates of the wealthy living therein. 


\section{Need for the Study}

There is need for strong global advocacy by the researcher to draw attention to women as earners. Women are recognized as agents of socio-economic growth with autonomy of decision making. (Report on the Work of Working Group of Feminist Economists during the preparation of $11^{\text {th }}$ Five year Plan: 2007-2012) By virtue of augmenting employment rate and entrepreneurship activities, women are becoming economically autonomous. At the same time, there is a necessitate for investment rising for working women due to diverse reasons, such as in times of the recent global financial crisis, more job losses by men in the families which has transformed the active economic role to women in their families. Women are progressively more entrepreneurial in nature, grabbing new business prospects. Thus women are becoming one of the largest groups of investors across the globe. Many households shy away from stock markets, because of lack of adequate financial knowledge on stocks, the stock market working and asset pricing. This leads to stumpy retail participation putting the Indian stock markets in "dilemma".

\section{Statement of Problem}

Indian stock markets mobilize a very small fraction of household financial savings in India. Indian Stock market is beleaguered with severe price volatility and suffers from menace of over speculation and excessive price fluctuation

\section{Scope of the Study}

The rationale behind every academic research undertaken is societal progress. This study aims to enrich the Indian equity market; Retail investors are individual investors who invest in small quantities. The term investor is generic term that encompasses all market participants. This study endeavors to act as an eye-opener for the working women investors to enhance more retail equity participation and promulgate equity investment habit which in turn reinforce the Indian Capital markets. In this study working women within the age group of 18 years to 60 years are 
declared as respondents as they form the mainstream of working women group. This study focuses on Indian Working women in Chennai metropolitan. The scope of this study is also extended to various segments of society such as Professional advisors, banks and financial institutions, government, academicians and media.

\section{Objective of the Study}

To study the perception of Indian Working Women considering Equity as an Investment Avenue

\section{Hypothesis of the Study}

\section{Hypothesis 1}

Ho: There exists no influence of the demographic variables on the rationale behind stock market participation among the Indian Working Women

H1: There exists influence of the demographic variables on the rationale behind stock market participation among the Indian Working Women

\section{Hypothesis 2}

Ho: There exists no influence of the demographic variables on the reason for the resistance for the stock markets among the Indian Working Women

H1: There exist influences of the demographic variables on the reason for the resistance for the stock markets among the Indian Working Women

\section{Research Design}

The methodology adopted for the study is based on primary data. The primary data is collected through well framed and structured questionnaire to elicit the perception of Indian Working women. Simple random sampling has been used to collect responses from the Indian Working Women.

The primary data was collected from the working women in person by the researcher through survey method. For a few respondents 
who were busy during trading hours and those who experienced difficulty in language, responses were collected orally by the researcher in a one-to-one interview manner. A mail survey instrument was also chosen as the method of collecting the selfreported data. Despite potential problems with non-response, mail questionnaires are commonly held as the most efficient means of collecting empirical data. The researcher developed a web page that contained the survey questionnaire and allowed respondents to mail their response to an email account specifically created for this purpose.

\section{Data Analysis}

The researcher has used for Statistical Package for Social Sciences (SPSS-17) to perform statistical techniques such as One way ANOVA has been employed to establish the influence of demographic variables on the reasons which facilitates and resist stock market participation among Indian Working Women.

\section{Empirical Results and Discussion}

Among the 100 respondents, 84 respondents are not interested to make the equity investment, 13 respondents prefer to make investment for obtaining Dividend and capital gains, and 3 respondents prefer to make equity investment for retirement planning purpose. 8 respondents resist to make the equity investment due to inadequate returns, 26 working women lack sufficient skills to trade in equity markets, 37 working women resist equities due to fear of losing the capital invested and 13 respondents oppose equity due to dissatisfied market regulators. In this section the researcher attempts to study the influence of demographic variables on the reasons which facilities and resist the stock market participation among the Indian Working Women. 
Table 1 Influence of Demographic variables on the Reasons for the stock market participation (Capital Investment preservation, Retirement planning, Dividends and Capital Gains)

\begin{tabular}{|c|c|c|c|c|c|c|}
\hline $\begin{array}{c}\text { Demographic } \\
\text { variables }\end{array}$ & Source & $\begin{array}{l}\text { Sum of } \\
\text { squares }\end{array}$ & $\mathrm{df}$ & $\begin{array}{l}\text { Mean } \\
\text { square }\end{array}$ & $\mathrm{F}$ & $\begin{array}{l}\text { Sig. } \\
\text { level }\end{array}$ \\
\hline \multirow{3}{*}{ Age group } & Between groups & 5.386 & 2 & 2.693 & \multirow{3}{*}{3.318} & \multirow{3}{*}{.004} \\
\hline & Within groups & 78.724 & 97 & .812 & & \\
\hline & Total & 84.110 & 99 & & & \\
\hline \multirow{3}{*}{$\begin{array}{l}\text { Martial } \\
\text { Status }\end{array}$} & Between groups & 3.132 & 2 & 1.566 & \multirow{3}{*}{2.539} & \multirow{3}{*}{.004} \\
\hline & Within groups & 59.828 & 97 & .617 & & \\
\hline & Total & 62.960 & 99 & & & \\
\hline \multirow{3}{*}{ Education } & Between groups & 1.414 & 2 & 2.707 & \multirow{3}{*}{3.831} & \multirow{3}{*}{.003} \\
\hline & Within groups & 82.546 & 97 & .815 & & \\
\hline & Total & 83.960 & 99 & & & \\
\hline \multirow{3}{*}{$\begin{array}{l}\text { Source of } \\
\text { information }\end{array}$} & Between groups & 4.849 & 2 & 2.424 & \multirow{3}{*}{3.774} & \multirow{3}{*}{.002} \\
\hline & Within groups & 62.311 & 97 & .642 & & \\
\hline & Total & 67.160 & 99 & & & \\
\hline \multirow{3}{*}{$\begin{array}{l}\text { Annual } \\
\text { Savings }\end{array}$} & Between groups & 9.564 & 2 & 4.782 & \multirow{3}{*}{5.087} & \multirow{3}{*}{.002} \\
\hline & Within groups & 91.186 & 97 & .940 & & \\
\hline & Total & 100.750 & 99 & & & \\
\hline \multirow{3}{*}{$\begin{array}{l}\text { Role in the } \\
\text { family }\end{array}$} & Between groups & 1.293 & 2 & 2.647 & \multirow{3}{*}{3.223} & \multirow{3}{*}{.004} \\
\hline & Within groups & 19.457 & 97 & .201 & & \\
\hline & Total & 20.750 & 99 & & & \\
\hline
\end{tabular}

Source: Computed Data

From Table 1, it is found that influence of demographic variables such as age $(\mathrm{F}=3.318, \mathrm{p}=.004)$, Marital Status $(\mathrm{F}=2.539, \mathrm{p}=.004)$, Education $(\mathrm{F}=3.831, \mathrm{p}=.003)$, Source of information about the investment avenues $(F=3.774, p=.002)$,Annual Savings $(F=5.087$, $\mathrm{p}=.002)$, and role in the family $(\mathrm{F}=3.223, \mathrm{p}=.004)$ on the reasons for the stock market participation is significant at 5\% level for the sample respondents namely the Indian Working women. The Working women prefer to make equity investment for several reasons such as Dividends and capital gains, retirement planning purpose and Capital Investment Preservation. The influence of demographic variables on the working women's preference for stock market investment is estimated through mean comparison. Further it can be observed from that out of total sample unit of 100 working women respondents, age (mean=3.318), Marital Status $($ mean $=2.539)$, Education $($ mean $=3.831)$, Source of information 
about the investment avenue such as newspapers and magazines, media, friends and relatives, Financial advisors (mean=3.774), Annual savings (mean $=5.087$ ), Women's role in the family as principal earner or secondary earner (mean= 3.223) are the predominant demographic variables which exhibits the significant influence on the working women's preference to make equity investment.. With increasingly complex financial products in the market place, investors' financial literacy has become ever more important. Indian working women's age, marital status, education, income, role in the family and the source of information about the investment avenue serves as the best proxy variables to determine the working women's preference for equity as an investment avenue. Thus, the null hypothesis is rejected, there exist the significant influence of the demographic variables on the reasons which facilities the stock market participation among the Indian Working Women. Results are similar to past research undertaken in different countries.

Meier and Sprenger (2012) highlight the significance of time preferences, initially modeled by Liabson (1997), in the process of obtaining financial information. The author point out that individual should incur costs in order to acquire financial literacy to obtain future return on their human capital investment. Furthermore, the researchers show that individuals obtain greater value in the future benefits of being financially literate.

Likewise, Heshmat, Nesma Ahmed (2012) investigates the factors that affect female Saudi students who are considered as potential non professional investors. The author highlights that variables such as age, income, grade point average (GPA), and grade obtained in financial courses, and risk tolerance affects the stock ownership decisions among female students. Furthermore, the results indicate that female students are more likely to own stocks if they have high level of financial education. 
Table 2 Influence of Demographic variables on the Reasons behind the Resistance for Stock Market Participation (Inadequate returns, Inadequate information, Fear of losing the capital, Dissatisfied with the regulator, Inadequate financial resources)

\begin{tabular}{|c|c|c|c|c|c|c|}
\hline $\begin{array}{c}\text { Demographic } \\
\text { variables }\end{array}$ & Source & $\begin{array}{l}\text { Sum of } \\
\text { squares }\end{array}$ & $\mathrm{df}$ & $\begin{array}{l}\text { Mean } \\
\text { square }\end{array}$ & $\mathrm{F}$ & $\begin{array}{l}\text { Sig. } \\
\text { level }\end{array}$ \\
\hline \multirow{3}{*}{ Occupation } & $\begin{array}{l}\text { Between } \\
\text { groups }\end{array}$ & 5.204 & 4 & 1.301 & \multirow{3}{*}{2.699} & \multirow{3}{*}{.003} \\
\hline & Within groups & 45.786 & 95 & .482 & & \\
\hline & Total & 50.990 & 99 & & & \\
\hline \multirow{3}{*}{$\begin{array}{l}\text { Sources of } \\
\text { Information } \\
\text { about the } \\
\text { Investment } \\
\text { avenue }\end{array}$} & $\begin{array}{l}\text { Between } \\
\text { groups }\end{array}$ & 6.182 & 4 & 1.546 & \multirow{3}{*}{2.408} & \multirow{3}{*}{.005} \\
\hline & Within groups & 60.978 & 95 & .642 & & \\
\hline & Total & 62.960 & 99 & & & \\
\hline \multirow{5}{*}{$\begin{array}{l}\text { Annual } \\
\text { savings }\end{array}$} & $\begin{array}{l}\text { Between } \\
\text { groups }\end{array}$ & 12.294 & 4 & 3.074 & \multirow{5}{*}{3.301} & \multirow{5}{*}{.001 } \\
\hline & Within groups & 88.456 & 95 & .931 & & \\
\hline & Total & 100.750 & & & & \\
\hline & Within groups & 91.186 & 97 & .940 & & \\
\hline & Total & 100.750 & 99 & & & \\
\hline \multirow{3}{*}{$\begin{array}{l}\text { Role in the } \\
\text { family }\end{array}$} & $\begin{array}{l}\text { Between } \\
\text { groups }\end{array}$ & 1.293 & 2 & 2.647 & \multirow{3}{*}{3.223} & \multirow{3}{*}{.004} \\
\hline & Within groups & 19.457 & 97 & .201 & & \\
\hline & Total & 20.750 & 99 & & & \\
\hline
\end{tabular}

From Table 2, it is found that influence of demographic variables such as Occupation $(\mathrm{F}=2.699, \mathrm{p}=.003)$, Sources of the information about the investment avenue $(\mathrm{f}=2.408, \mathrm{p}=.005)$, annual savings $(\mathrm{F}=3.301, \mathrm{p}=.001)$ and the role of the women in the family $(\mathrm{F}=4.079$, $\mathrm{p}=.004$ ) on the reasons for the stock market resistance is significant at $5 \%$ level for the sample respondents namely the Indian Working women. The Working women resist to make equity investment for several reasons such as Inadequate returns, Inadequate information, Fear of losing the capital, Dissatisfied with the regulator, Inadequate financial resources. The influence of demographic variables on the working women's preference for stock market investment is estimated through mean comparison. Further it can be observed from that out of total sample unit of 100 working women respondents, Occupation (mean=2.699), Annual 
Savings (mean= 3.301), Source of information about the investment avenue such as newspapers and magazines, media, friends and relatives, Financial advisors (mean $=2.408)$, Women's role in the family as principal earner or secondary earner (mean $=4.079)$ are the predominant demographic variables which exhibits the significant influence on the working women's resistance to make equity investment. Indian working women's occupation, annual savings, Source of information about the investment avenues, role in the family as the principal earner and secondary earner serves as the best proxy variables to determine the working women's resistance for equity as an investment avenue. Thus, the null hypothesis is rejected; there exist the significant influence on the demographic variables on the reasons which resist the stock market participation among the Indian Working Women. Results are similar to past research undertaken in different countries. Favilukis, Jack (2013) emphasized that stock market played a major role in increasing wealth inequality. Priyanka Dhoot and Vidhya Hittalmani (2012) examine to understand the women perceptions towards their personal finance and investment decisions. The authors highlight that factors like access to education, social sanction for women's education and phenomenon of "working women" have brought about a perceptible change in the attitudes of both men and women towards money. The author suggest that women show preference for financial assets with a high degree of liquidity while men are more willing to sacrifice financial asset liquidity in order to earn higher, risk-adjusted total investment returns.

\section{Conclusion}

Retail investors are considered as the backbone to the equity market. Retail investors especially working women force seem to be opting for attractive asset classes such as gold, real estate to park their funds. Working women unearth the stock market activities to be excessively complicated and complex to grasp. The individual investor's participation cascades down due to failure to restore the women investor's confidence. Financial literacy level is quite stumpy among the Indian working women. Government of India must effectively indulge in formulating effective strategies to equip 
adequate financial knowledge among the Indian working women. There is zilch superior way of empowering the investor than taming their financial literacy among the Working women. Government support and media must play an effective role in promoting the equity culture among the women. Effective participation in the investor education programmes boosts the women's confidence which enables them to get best insights of various equity oriented securities. While the market rudiments reinforced as the year progressed, dedicated policy measures encircling all specialty of market activity further vitalized the regulatory infrastructure and reposed the investor confidence. SEBI is looking forward to explore effective ways to employ modern technology and social media to make learning of stock markets and financial education easy and entertainment based. SEBI would persistently endeavors to make Indian stock market world class by focusing on "Protection of investor's interests and promote regulation for market development".

\section{References}

Balwin, R., Forslid, R., Martin, P., \& Robert, N. F. (2003). The core Periphery Model:Key feature and effects. Public Policy and Economic Geography, 213-235.

Brulhart, M. (1998). Economic Geography Location and Trade: The evidence. The World Economy .

Fujita, M. (1989). Urban Economic Theory: Land use and city size. Cambridge: Cambridge University Press.

Fujita, M., Krugman, P., \& Venables, A. (1999). The Spartial Economy: Cities ,Regions and International Trade. Cambridge: Cambridge International Press.

Gayer, H. S. (2002). International Handbook of urban systems :Studies of urbanization and migration in advanced and developing countries. Cheltenham :Edward Ellagar.

Handerson, E. L., \& Thisse, J. F. (2004). Handbook of regional and urban economics. Amsterdam: Elsevier.

Huriot, J. \&. (2000). Economies of cities : Theoretical Prespective . Cambridge: Cambridge University Press.

Krugman, P. (1991). Geography and Trade. Cambridge: MIT Press. 
Krugman, P. (2010). The new Economic Geography: Now middleaged. The Association of American Geographers, 1-19.

Marshall, A. (1890). Principles of Economics. London: MacMillian.

McCann, P. (2007). Urban and Regional Economics. New York: Oxford University Press.

Rosenthal, S. S., \& Strange, W. C. (2003). Geography , Industrial, Organisation and Agglomeration. Review of Economics and Statistics , 377-393.

Saha, S. (2015). An informal industrial district syntax : From Marshall to Krugman. Splint International Journal of Professional, 2 (5), 17-23.

Saha, S. (2015). In search of effective instruments to tie up skill: An informal industry argument. Desh Vikas , 1 (2), 219-227.

Saha, S. (2015). Localized informal agglomeration : A classical syntax. Desh Vikas , 129-136.

Saha, S. (2015). Sticky Knowlwdge Externity: An instrument to access inovation. International Journal of Inovative Research and Development , 4 (2), 54-60. 